\title{
Spare the rod! Implications for community safety partnerships in removing the reasonable chastisement defence in Wales
}

\section{Colin Rogers ${ }^{1} \cdot$ Garry Thomas $^{1}$}

Accepted: 29 November 2021 / Published online: 4 January 2022

(c) The Author(s), under exclusive licence to Springer Nature Limited 2021

\begin{abstract}
Parental discipline of children has long included the use of corporal punishment and has drawn conflicting views upon its effectiveness and its long-term effects upon individuals and society as a whole. This article considers the use of such a tactic by individuals, discussing its use and the research surrounding it at the international and national levels. It explores the introduction of the 'The Children (Abolition of the Defence of Reasonable Punishment) (Wales) Act,' which will become law in Wales during March 2022. This Act, whilst not creating a specific criminal act in itself, removes the defence of reasonable chastisement for parents when correcting their children in Wales. The article further considers the potential impact that the removal of the reasonable chastisement clause may have for those agencies charged with overseeing the safety of children, including the potential increase in reported cases and the issues of media and public awareness.
\end{abstract}

Keywords Reasonable chastisement · Corporal punishment · Wales · Partnership working

\section{Introduction}

Corporal punishment of children has long been the subject of discussion and debate. Indeed, as Wegner (2005) points out, the perceived wisdom of parental discipline utilising corporal punishment can be seen in the Book of Proverbs in the Christian Bible, written, it is believed, between the tenth and fourth centuries BCE. Across the world, people from different religions, faiths and cultures exhibit different attitudes and beliefs towards the use of corporal punishment to discipline children. For example, Straus (2017), suggests in the USA that corporal punishment is so

Colin Rogers

colin.rogers@southwales.ac.uk

1 University of South Wales, Pontypridd, UK

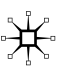


commonly accepted that it is taken for granted and is a daily life for parents and children. Indeed, so prevalent is the approach that UNICEF (2014) has found that, on average, around $80 \%$ of children between the ages of 2 and 14 are subjected to some form of violent discipline in the home. It would appear that the use of corporate punishment is quite common in homes in many countries. Therefore, when governments consider introducing legislation to remove the parental right to discipline their children using corporal punishment, there are several important aspects that need consideration. This is so in Wales as a result of the removal of 'reasonable chastisement' clause used as a defence in law for the use of corporal punishment to discipline children. The Children (Abolition of the Defence of Reasonable Punishment) (Wales) Act, (Welsh Government 2020a) becomes law in March 2022, and although not introducing a new criminal act, it alters the way in which children can be chastised. The question arises, therefore, as to what the possible implications a change in such legislation may have for agencies such as community safety partnerships (CSPs) in England and Wales.

\title{
Reasonable chastisement and corporal punishment in context
}

The term corporal punishment is defined by the United Nations (UN) Committee on the Rights of the Child (2006, p. 4) as follows:

\begin{abstract}
The Committee defines "corporal" or "physical" punishment as any punishment in which physical force is used and intended to cause some degree of pain or discomfort, however, light. Most involves hitting ("smacking”, "slapping”, "spanking") children, with the hand or with an implement - a whip, stick, belt, shoe, wooden spoon, etc. But it can also involve, for example, kicking, shaking or throwing children, scratching, pinching, biting, pulling hair or boxing ears, forcing children to stay in uncomfortable positions, burning, scalding, or forced ingestion (for example, washing children's mouths out with soap or forcing them to swallow hot spices). In the view of the Committee, corporal punishment is invariably degrading. In addition, there are other non-physical forms of punishment that are also cruel and degrading, and thus, incompatible with the Convention. These include, for example, punishment which belittles, humiliates, denigrates, scapegoats, threatens, scares, or ridicules the child. (United Nations 2006: 4)
\end{abstract}

More recently, Straus (2017) defined corporal punishment within the context of the reasonable chastisement of children as being the use of physical force with the intention of causing a child to experience pain, but not injury, for the purpose of correction or control of the child's behaviour.

In general, according to Benjet and Kazdin (2003), there appear to be three main positions on corporal punishment namely;

(1) Anti-corporal punishment, where corporal punishment has harmful consequences for short and long-term child development, 
(2) Conditional corporal punishment, where corporal punishment may not necessarily be positive or negative, but may be either or both depending on the circumstances, and

(3) Pro corporal punishment, where corporal punishment is not only beneficial but also to refrain from using it is detrimental.

Clearly, if this idea is correct, then these main positions may be influential in the way in which research into this topic is carried out. In light of this, Larzelere (2000a) evaluated 38 studies into the outcomes of using corporal punishment (non-abusive spanking) on under 13-year-old children. The evaluation found that the outcomes were almost equally divided between beneficial (32 per cent), detrimental (34 per cent), and neutral or mixed (34 per cent) outcomes (Larzelere 2000a). Larzelere (2000a) argues that corporal punishment is most beneficial when it is used in a non-abusive way by loving parents on 2 to 6-year-old children and is most detrimental when used too frequently. This viewpoint is agreed by Hicks-Pass (2009, p. 79) who suggests that severe, continual abusive physical discipline is detrimental to any child. Of course, defining conclusions regarding the outcomes of "ordinary" corporal punishment are more difficult to reach.

In terms of the impact of the use of corporal punishment upon children, researchers tend to agree that it stimulates negative responses from the child. Gershoff (2002) undertook a large meta-analysis of the use of corporal punishment by parents and the associated behaviours and experiences of children. This analysis found that there were ten main negative behaviours and experiences associated with corporal punishment; (1) Poor moral internalisation, (2) Poor quality relationship between parent and child, (3) Mental health problems in childhood, (4) Aggression in childhood, (5) Delinquent and anti-social behaviour in childhood, (6) The child a victim of abuse, (7) Aggression and violence when an adult, (8) Criminal and anti-social behaviour when an adult, (9) Mental health problems when an adult, and (10) Abuse of a child or spouse when an adult (Gershoff 2002).

The findings of Gershoff (2002) are supported by Pfeiffer (2014, p. 96) from a study between 2007 and 2008 in Germany of 45,000 ninth-grade students, which found that children who had received severe corporal punishment from their parents were five times more likely to become multiple violent offenders than those who had been raised without violence. They also used cannabis five times more often and skipped school four times more often, at least ten times a year. In their ecological study of corporal punishment bans and physical fighting in adolescents in 88 diverse countries, Elgar et al (2018) found that countries who had introduced bans on corporal punishment in schools and in the home experienced less frequent fighting in male and female adolescents. Countries who had only introduced bans in schools saw less frequent fighting in female adolescents, but not in male adolescents compared to countries who did not ban corporal punishment in schools and in the home. Conversely, however, Gunnoe and Mariner (1997) argue that claims that corporal punishment (spanking) teaches aggression seem unfounded and that beneficial and detrimental outcomes of spanking are dependent on the child and the family context. 
Much of the findings discussed here have been confirmed by other researchers such as Afifi et al (2012) Becker (2018) and Dobbs (2005).

Despite the apparent overwhelming evidence in research that supports the view that corporal punishment in parental discipline is a negative concept with detrimental outcomes for children and society alike, there are some who point to perceived benefits. For example, Larzelere (2000a, b) Waterston (2000), and Gershoff (2002) who point to some of the studies which indicate immediate compliance following corporal punishment. Waterston (2000) and Hain (2000) suggest that there is no evidence that occasional smacking is harmful, and indeed that the trivial nature of the event would not lead to a psychological disorder. However, there is the danger that this approach teaches that violence is a solution to interpersonal conflict, makes other methods harder to use, and can actually increase aggression.

Despite the research surrounding the use of corporal punishment in general, the question also arises concerning the experiences in countries who have already accepted the removal of corporal punishment for disciplining children. In Finland and Sweden, for example, Ellonen et al (2015) undertook a study of parental attitudes towards corporal punishment 30 years after corporal punishment had been prohibited. Their study showed that even after 30 years, some parents in both Finland and Sweden still approved the use of corporal punishment. However, Finnish parents have a more accepting attitude to corporal punishment than Swedish parents, which may be influenced by cultural values and beliefs. For example, 17.3 per cent of Finnish parents thought that it was acceptable to slap a child if they made the parents angry, whilst only 3.1 per cent of Swedish parents thought the same. By comparison, 8.8 per cent of Finnish parents thought that it was acceptable to shake a child if they made the parents angry, whilst 13.8 per cent of Swedish parents thought the same (Ellonen et al. 2015). Even in countries such as Finland and Sweden, there are still parents that use corporal punishment to chastise their children, even though it has been made illegal by the authorities in those countries and many others.

Given the propensity of the use of corporal punishment as discipline for children across the world, it is worth noting the attitudes of other European countries. Gracia and Herrero (2008) undertook a study of the acceptability of corporal punishment in 14 Member States of the European Union (EU), who had prohibited corporal punishment by 1999 . Their study found that at the individual level, 'men, older adults, and those with lower educational level reported significantly higher levels of acceptability' compared to other groups. At the State level, 'the existence of laws prohibiting physical punishment of children and a lower number of child maltreatment deaths were significantly associated with lower levels of acceptability of physical punishment of children' (Gracia and Herrero 2008, p. 214).

The UK (with the exception of Scotland) has prohibited corporal punishment in schools, but not in the home and therefore, appears to fall into the 'anti-corporal punishment' and 'conditional corporal punishment' positions advocated by Benjet and Kazdin (2003) and both the 'anti-smackers' and 'pro-smackers' factions highlighted by Pete (1998).

Corporal punishment was abolished in state schools in England and Wales by the Education (No. 2) Act 1986 (Home Office 1986) and in all schools by the School Standards and Framework Act 1998 (Home Office 1998). However, the reasonable 
chastisement of children by parents and legal guardians in the home is still currently legal in parts of the UK. However, there has been a growing international movement led by the United Nations and the Global Initiative to End All Corporal Punishment of Children (2021) (now the End Violence Against Children Partnership) to abolish the reasonable chastisement of children, both in the school and in the home.

\section{The situation in the United Kingdom}

In 1989, the Children Act 1989 (Home Office 1989) was introduced to consolidate and clarify the existing legislation in relation to children. Sections 17 and 47 of the Act set out the duties of local authorities to protect the welfare of children and Section 31 authorised the national society for the prevention of cruelty to children (NSPCC), (founded in 1884), to apply directly to a court for a care or supervision order, if it believes that the child concerned is suffering, or is likely to suffer, significant harm. In 1998, Section 131 of the School Standards and Framework Act 1998 amended Section 548 of the Education Act 1996 (Home Office 1996, pp. 300-301) and abolished the use of corporal punishment in all schools, including those providing specified nursery education (Home Office 1998, pp. 152-153; Keating 2006).

The Children and Social Work Act 2017 (Home Office 2017) amended certain sections of the Children Act 2004 (Home Office 2004) to replace local safeguarding children boards (LSCBs) with new local Safeguarding Partnerships, which included; the local authority, the national health service (NHS), the clinical commissioning group (CCG), and the local police force, who are responsible for safeguarding and promoting the welfare of children (Foster 2020). This also provided statutory guidance for inter-agency Safeguarding Partnerships when working together to safeguard children. However, due to devolution in the UK, the Northern Ireland Executive, the Scottish Government, and the Welsh Government have introduced their own legislation in relation to the welfare and corporal punishment of children.

Currently, England is the largest of the four nations that form the UK and does not have its own devolved government (Office for National Statistics, (ONS) 2020). The UK Government governs England in relation to all matters, and England observes UK legislation. Therefore, England adheres to Section 58 of the Children Act 2004 (Home Office 2004, p. 38) and has not abolished the corporal punishment of children or the defence of reasonable chastisement for common assault.

Northern Ireland has a devolved Northern Ireland Executive, which has legislative control over certain transferred matters, including; health, social services, and education (GOV.UK 2019a; ONS 2020). However, Article 2 of The Law Reform (Miscellaneous Provisions) (Northern Ireland) Order 2006 (Home Office 2006, pp. 1-2), which is very similar to Section 58 of the Children Act 2004 (Home Office 2004, p. 38), was introduced by the UK Government under an Order in Council (or secondary legislation) at a time of direct rule between 2002 and 2007, when the Northern Ireland Assembly was suspended. This Order (Home Office 2006, pp. 1-2) did not abolish the corporal punishment of children or the defence of reasonable chastisement in Northern Ireland. Thus, legislation in Northern Ireland and England still allows parents to reasonably chastise their children. 
Bunting et al. (2008) found from their survey that the majority (over 70 per cent) of parents in Northern Ireland would not support a ban on the smacking of children of any age. Nearly, half (47.4 per cent) of parents reported they had used physical discipline at some time. Of these parents, all reported using minor physical discipline and two per cent reported that they had used severe or extreme physical discipline. However, over three-quarters (76 per cent) of respondents indicated that they would support some form of legislative change. Bunting et al. (2008, 2010, p. 369) also found that many parents continue to use physical discipline as a last resort, even though the 'majority of parents believe that using it is upsetting to both themselves and their children.'

Scotland also has a devolved Scottish Government, which also has legislative control over certain transferred matters, including; health, social services and education (GOV.UK 2019b; ONS 2020) Scotland was the first devolved nation in the UK to move to abolish the physical punishment of children. A draft proposal of the Children (Equal Protection from Assault) (Scotland) Bill (Scottish Parliament 2017a) was first lodged in May 2017 by John Finnie, MSP and after consultation, the final proposal for the Bill was lodged in October 2017 (Scottish Parliament 2017b, c). In September 2018, the Children (Equal Protection from Assault) (Scotland) Bill (Scottish Parliament 2018) was introduced to the Scottish Parliament for debate and finally in October 2019 the Bill was passed and the Children (Equal Protection from Assault) (Scotland) Act 2019 received Royal Assent on 7th November 2019 (Scottish Government 2019; Scottish Parliament 2019). Section 1(2) of the Children (Equal Protection from Assault) (Scotland) Act 2019 also repealed Section 51 of the Criminal Justice (Scotland) Act 2003 (Scottish Parliament 2003, 2019) and thus, abolished the defence of reasonable chastisement. However, the Children (Equal Protection from Assault) (Scotland) Act 2019 did not become law until 7th November 2020, when Scotland joined 61 other countries in abolishing the physical punishment of children (Scottish Government 2020). The Scottish Government (2020) also provided advice to parents and members of the public on how the law was changing, including to call the police, local authority, or even 999 in the right circumstances.

\section{The current position in Wales}

In 2011, the then National Assembly for Wales (NAW) passed the Rights of Children and Young Persons (Wales) Measure 2011 (NAW 2011), which placed a duty on NAW Ministers to have due regard to the requirements of the UN Convention on the Rights of the Child (UN General Assembly 1989) when making decisions on provisions for any enactment, on new policy or when reviewing any existing policy.

Consequently, the Children (Abolition of Defence of Reasonable Punishment) (Wales) Bill was agreed and passed by the NAW on 28th January 2020 and received Royal Assent on 20th March 2020 (Senedd Cymru 2019) becoming the Children (Abolition of Defence of Reasonable Punishment) (Wales) Act 2020 (Senedd Cymru 2020a). Section 1 of the Act abolished the defence of reasonable chastisement in relation to the corporal punishment of children in Wales (Senedd Cymru 2020a, p. 1). The Welsh Government set up a Task and Finish Group for the Children 
(Abolition of Defence of Reasonable Punishment) (Wales) Act 2020 to advise the Strategic Implementation Group and the Welsh Government on reviewing (or revising) the working processes and procedures of relevant organisations and the training and guidance for professionals and practitioners to reflect the change in legislation when it comes into force on 21st March 2022 (Senedd Cymru 2020b, pp. 1-2).

The Children (Abolition of Defence of Reasonable Punishment) (Wales) Act 2020 (Senedd Cymru 2020a) does not create any new offences, but removes the defence of reasonable chastisement under Section 58 of the Children Act 2004 (Home Office 2004, p. 38) for the offence of common assault. Thus, any physical assaults on children or adults will be prosecuted under Section 39 of the Criminal Justice Act 1988 (Home Office 1988) and Sections 18, 20 and 47 of the Offences against the Person Act 1861 (Home Office 1861).

The abolition of the defence of reasonable chastisement in Wales will not become law until March 2022, which gives the Welsh Government a period to help the population of Wales understands the changes in the law and for the Welsh Government to learn the lessons from other countries who have already prohibited the corporal punishment of children.

\section{Possible implications for partnerships}

Since 1998, England and Wales have seen the introduction of Community Safety Partnerships (Home Office 1998). These partnerships were introduced to involve many agencies, not just the police, in tackling crime and disorder. A major agency involved in this structure is the Local Authority, which includes social, children and welfare services. As such, this partnership approach has seen the introduction of partnership working known as MAPPA (Mappa 2021) MAPPA stands for MultiAgency Public Protection Arrangements. It is the process and arrangements through which the community safety partnership agencies work together with other agencies to manage the risks posed by violent and sexual offenders living in the community in order to protect the public. Whilst not being a statutory body in itself, it is a mechanism through which agencies can carry out their statutory responsibilities and protect the public in a co-ordinated manner. Currently, there are five general ways in which incidents involving abuse of children are reported. These are;

1. Where the public report the matter directly to the police

2. Where the public report the matter directly to Social services

3. Where the public report the matter to a helpline, e.g., NSPCC

4. Where the Health or education bodies report the matter to the police and

5. Where the health or education bodies report the matter to Social services

Once the incident has been verified, it is normally passed to the MAPPA group for action. Clearly, such a change as the removal of lawful chastisement as a defence for punishing children will have a direct impact upon those dealing with such incidents. The question remains as to what this change could potentially mean for 
those, directly and indirectly, involved for those charged with the implementation of administering such public protection? The first possibility, and probably the one that will feature most in the mind of professionals working in this field, is a potential increase in reporting of incidents.

\section{Reporting corporal punishment to the authorities}

Research suggests that there are several factors that may influence the reporting of corporal punishment to the authorities. Burns et al (2021) for example, conducted a study on the attitudes of people in five European countries (Austria, Estonia, Ireland, Norway, and Spain) on reporting corporal punishment to child protection authorities. Burns et al (2021, p. 5) found that corporal punishment was not generally acceptable in all five countries, all of whom had prohibited the use of corporal punishment. They also found that with the majority of respondents there was compatibility between a person's attitude to corporal punishment and their views on reporting it. However, there were two significant groups that provided a mismatch; the first group being those that disapprove of corporal punishment, but do not want to report it, and the second group that approves of corporal punishment, but do want it to be reported (Burns et al. 2021, p. 5). Burns et al. (2021, p. 7) suggest that this mismatch may be related to the respondents' confidence in the child protection authorities, as 'respondents with low confidence are more likely to not report, whereas those with high confidence are more likely to report.'

In a separate study considering the confidence of populations in child protection systems in England, Finland, Norway and California, USA, Juhasz and Skivenes (2017, p. 1337-1338) found that generally only just over 40 per cent of the population has quite a lot or a great deal of confidence in these systems. Finland had the greatest confidence in the system, followed by Norway, England and California. Juhasz and Skivenes (2017, p. 1339-1340) also found that there were three variables that could be related to higher confidence levels; (1) A left-wing political orientation, (2) Lower age, and (3) Higher education. Thus, it would appear that younger, left-wing, higher-educated people are more likely to have confidence in child protection systems. This same group may also have lower levels of acceptability of corporal punishment. (See Gracia and Herrero (2008) above).

Ashton (2001, p. 396) found that a person's (in this case a social worker's) approval or disapproval of corporal punishment contributes to that person's perception of parental behaviour and their response to that behaviour. Thus, if a person approves of corporal punishment, they are less likely to report a parent for illegal maltreatment. However, Ashton (2001, p. 397) also advises that there are other factors that can influence a person's decision to report maltreatment, including the characteristics of each individual case. In a later study (also involving social workers), Ashton (2004, p. 990) found that ethnicity and immigrant status (whether or not born in the USA) were also factors in the reporting of parents for illegal maltreatment due to corporal punishment. Persons of white ethnicity were most likely to report parents for maltreatment, whilst persons of Asian ethnicity were least likely 
to report parents and persons born in the USA were more likely to report than those born outside the USA.

McTavish et al. (2017) conducted a study into the mandatory reporting of child maltreatment by physicians, nurses, child protection service professionals, teachers, psychologists, therapists, social workers, dentists, domestic violence workers, and police officers in 12 different countries (Australia, Brazil, Canada, Cyprus, El Salvador, Finland, Israel, Norway, South Africa, Sweden, Taiwan, and the USA). McTavish et al. (2017, p. 5) found that although mandatory reporting by those legislated to do so was generally thought to be of benefit to children and assisted in identifying more cases of child maltreatment, there were also some negative issues to mandatory reporting, including re-victimization of the child. Therefore, there was a reluctance by some mandatory reporters to report maltreatment without some form of physical evidence. In a similar study in Israel, Tirosh et al. (2003) examined physician's views on corporal punishment and the reporting of child maltreatment. Tirosh et al (2003, p. 932) found that 58 per cent of the physicians in their study approved of corporal punishment, which significantly affected their willingness to report maltreatment. They also found that paediatricians were more tolerant towards corporal punishment than family practitioners and immigrant physicians were much more tolerant to corporal punishment than those educated in Israel (Tirosh et al. 2003, p. 932). (See Ashton (2004) above).

It would appear those cultural backgrounds and beliefs still play a significant role in people's attitudes to corporal punishment and their willingness to report child maltreatment to the authorities, including child care professionals, who in many countries have a mandatory duty to report child maltreatment. People's confidence in the child protection authorities is also a factor in their willingness to report maltreatment.

Consequently, The Welsh Government (2020c), anticipates that initially there will be an increase in the number of incidents of physical punishment reported, but that this will decrease in the medium to long term as the legislation is accepted and the use of physical punishment declines. The Welsh Government Police Liaison Unit (PLU) conducted research with the four Welsh police forces in relation to the number of identified offences of Common Assault and Cruelty to Children, where reasonable chastisement was used as a defence or considered in the decision-making process. The PLU found that annually the estimated number of potential offences fitting these criteria across Wales and requiring investigation would be 274 (DyfedPowys Police, 39; Gwent Police, 56; North Wales Police, 57 and South Wales Police, 122) (Welsh Government 2020a). The PLU also found that malicious reporting by ex-partners was prevalent in these statistics (Welsh Government 2020a).

The Welsh Government (2020a, pp. 109-113) observed that there were similarities between Wales and New Zealand in their political and legal systems, and New Zealand has prohibited the physical punishment of children since 2007. In the absence of other data, the number of prosecutions that might occur in Wales as a result of the implementation of the legislation in March 2022, may be estimated from New Zealand's data. Using New Zealand as a proxy, the Welsh Government (2020c, p 10) estimated that there would be approximately 37 prosecution cases over 5 years. As common assault is a summary offence generally prosecuted in the 
Magistrates Court, the Welsh Government (2020c, p 12) do not envisage that there will be any impact on Her Majesty's Prison and Probation Service (HMPPS). However, the Welsh Government (2020a, pp. 91-101) has identified that in the short term, due to increased reporting, there may be some impact for the Police Service, the CPS, the DBS and Local Authority Health, Social Services, and Education Departments.

As part of the consultation data submitted by New Zealand, McCoskrie (2019) provided an 'Analysis of New Zealand's 2007 Anti-Smacking Law.' McCoskrie (2019, p. 4; 15; 17-18 and 21) indicated that over a 7-year period since 2007, the physical abuse of children reported to the police had risen by 136 per cent, sexual abuse by 43 per cent, child neglect by 45 per cent and 71 children had died as a result of child abuse. In addition, the number of cases of physical abuse found by Child, Youth and Family (CYF) (New Zealand) had increased by 42 percent since 2007 (McCoskrie 2019, p. 4 and 16-17) and the Ministry of Health (New Zealand) had reported a 132 per cent increase in the number of children diagnosed with emotional and/or behavioural problems and an increase of 71 per cent in the number of children hospitalised with mental and behavioural problems (McCoskrie 2019, p. 4 and 22-23). McCoskrie (2019, p. 42) concluded that; 'There is not a single social indicator relating to child abuse and wellbeing that has shown significant and/ or consistent improvement in the 7 years since the passing of the anti-smacking law.'

There are reportedly a number of significant positive and negative impacts of the introduction of the legislation (Welsh government 2020b) Positive impacts include; (1) Children will receive the same legal protection from physical punishment as adults, and (2) A further reduction in the use and tolerance of the physical punishment of children. Negative impacts include; (1) Parents may be arrested by police and receive a criminal record, (2) The prosecution of a parent may have a negative impact on the child, (3) Potential disclosure to the authorities may impact on a parent's employment prospects, and (4) an increase in referrals to social services and the police. However, there is no international evidence to suggest that the latter will be overwhelmed.

Notwithstanding that there may already be some communication issues involved in cross-border arrangements between Wales and other countries (England, in particular, purely as it borders Wales) the Welsh Government (2020c) have made it quite clear that the law will apply to everyone within the territorial limits of Wales and would apply equally to visitors to Wales as to those normally resident in Wales. This may have greater implications for those residing near to the land border between Wales and England, who move freely between to two nations for work or leisure.

\section{Public awareness}

The abolition of the defence of reasonable chastisement in Scotland and now in Wales has received a mixed reception from the media (BBC 2018, 2019, 2020; Morris 2020; The Telegraph 2020). 
Whilst some media coverage has generally highlighted both sides of the argument, for and against abolition, some have also focused upon the fact that parents may become criminals if they smacked their children, (Smacking ban would criminalise parents, campaigners warn, BBC 2017). In general, however, the coverage tends to accentuate the negative rather than the positive aspects of abolition. For example, the internet magazine Spiked (Frawley 2018) published an article entitled; 'The Dystopia of the Child-Protection Industry', which refers to an earlier article by the BBC (Whewell 2018); 'Norway's Hidden Scandal.' Both articles refer to Norway, who abolished the defence of reasonable chastisement in 1987 and is regarded by the United Nations as one of the leaders in the field of child protection. The articles suggest that children are often taken into care of by the Norwegian authorities without a good reason for bad parenting and mild forms of physical punishment, and thus, criminalising parents (Frawley 2018; Whewell 2018). Wales Online (Mosalski 2020) published an article with the headline; 'Wales is Changing the Law to Ban Parents from Smacking Children', followed by a more negative sub-headline; 'Smacking is to be banned in Wales despite almost half of the people saying they do not support ending physical punishment for children.' Clearly, therefore, there are challenges and opportunities for the Welsh Government to portray a more positive image of the abolition of corporal punishment in the media.

Lansford et al. (2017) explored the challenges to be faced in the future to abolish corporal punishment and the defence of reasonable chastisement of children, which include the fact that most countries in the world still have not outlawed corporal punishment in the home and that even in those countries that have, many caregivers continue to believe in its use. Therefore, the evidence suggests that prohibitive legislation on its own is insufficient and should be accompanied by a long-term media campaigns and positive parenting strategies if existing parental attitudes and beliefs towards corporal punishment are to change. Heilmann et al. (2015) also support the argument that legislation should be used in tandem with large-scale information and awareness campaigns aimed at individuals, communities, and the whole population to inform them of the merits of positive parenting and the harm caused by physical punishment. They also advocated supporting parents in using positive parenting strategies and offering parenting programmes.

Lansford et al. (2017) further described the challenges to be faced in the future to abolish corporal punishment and the defence of reasonable chastisement of children:

The challenges going forward are twofold. First, although 50 [now 62] countries are a start in the course of universal banishment of corporal punishment, most countries in the world still have not outlawed corporal punishment in the home. Second, even for countries that have outlawed corporal punishment, many caregivers continue to believe that it is necessary to use corporal punishment, and even more report that their children continue to experience corporal punishment. Therefore, campaigns to promote awareness of legal bans and to educate parents regarding alternate forms of discipline are worthy of international attention and effort along with legal bans themselves. 
(Lansford et al. 2017: 42)

In support of the above, Bussmann et al. (2009) found that legal reforms need to be supported by intensive and long-term information campaigns in order to achieve the strongest impact, and it would appear that there is considerable evidence that providing support and education to parents can reduce their use of physical punishment and children's externalising behaviours. Furthermore, Durrant and Ensom (2017) also suggest that the combination of law reform and public education is more effective than either strategy alone in changing parental attitudes and behaviours.' Therefore, the evidence suggests that prohibitive legislation on its own is insufficient and should be accompanied by a long-term media campaigns and positive parenting strategies, if existing parental attitudes and beliefs towards corporal punishment are to change.

\section{Conclusion}

It must surely be only a matter of time before the law in England will mirror the situation of Scotland, Wales and other countries across the world in removing the reasonable chastisement clause available to parents in law. Community Safety Partnerships would do well to take note of what is known of the impact of such a policy especially given that the perceived impact of the Covid-19 pandemic on current and future resource allocation. As countries attempt to recover from economic austerity and the measures put in place to pay for policies to protect workers at home, reduced resources for public bodies may become the norm. Against this backcloth, the potential for increased workload, as referrals may come from a number of sources, coupled with the need to ensure children are protected by the law, may produce problems in the delivery of such services. Education of the public and awareness-raising of such changes in the law and their consequences must surely be a priority if agencies that deal with such issues are not to be inundated with calls for resolution. Research suggests that the use of public education campaigns and good public adherence to the ban has allowed other countries to achieve the objectives of the ban on corporal punishment as parental discipline.

Ultimately, though, it is the protection of children that is the main concern and partnership agencies, practitioners, and policy-makers need to understand the implications of such a change in the law concerning reasonable chastisement of children as a tool for parental control.

\section{References}

Afifi, T.O., N.P. Mota, P. Dasiewicz, H.L. MacMillan, and J. Sareen. 2012. Physical Punishment and Mental Disorders: Results from a Nationally Representative US Sample. Pediatrics 130 (2): $184-192$.

Ashton, V. 2001. The Relationship Between Attitudes Toward Corporal Punishment and the Perception and Reporting of Child Maltreatment. Child Abuse and Neglect 25 (3): 389-399. 
Ashton, V. 2004. The Effect of Personal Characteristics on Reporting Child Maltreatment. Child Abuse and Neglect 28 (9): 985-997.

BBC News. 2017. Smacking Ban Would Criminalise Parents, Campaigners Warn. BBC News, 17 July [Online]. https://www.bbc.co.uk/news/uk-wales-politics-40628598. Accessed 2 May 2021.

BBC News. 2018. Fresh Call for Smacking to be Outlawed in the Home. BBC News, 12 September [Online]. https://www.bbc.co.uk/news/education-45483347. Accessed 2 May 2021.

BBC News. 2019. Scotland Becomes First UK Country to Ban Smacking. BBC News, 3 October [Online]. https://www.bbc.co.uk/news/uk-scotland-scotland-politics-49908849. Accessed 2 May 2021.

BBC News. 2020. Wales to Bring in Smacking Ban After Assembly Vote. BBC News, 28 January [Online]. https://www.bbc.co.uk/news/uk-wales-51266509. Accessed 2 May 2021.

Becker, J. 2018. Corporal Punishment: Legal Reform as a Route to Changing Norms. Social Research: An International Quarterly 85 (1): 255-271.

Benjet, C., and A.E. Kazdin. 2003. Spanking Children: The Controversies, Findings, and New Directions. Clinical Psychology Review 23 (2): 197-224.

Bunting, L., M.A. Webb, and J. Healy. 2010. In Two Minds?-Parental Attitudes Toward Physical Punishment in the UK. Children and Society 24 (5): 359-370.

Bunting, L., M.A. Webb, and J. Healy. 2008. The 'Smacking Debate' in Northern Ireland: Messages from Research. Belfast: Northern Ireland Commissioner for Children and Young People.

Burns, K., H.S. Helland, K. Kriz, S.S. Sanchez-Cabezudo, M. Skivenes, and J. Strompl. 2021. Corporal Punishment and Reporting to Child Protection Authorities: Empirical Study of Population Attitudes in Five European Countries. Children and Youth Services Review 120 (105749): 1-10.

Bussmann, K.-D., C. Erthal, and A. Schroth. 2009. The Effect of Banning Corporal Punishment in Europe: A Five-Nation Comparison. Halle-Wittenberg: Martin-Luther-Universität.

Dobbs, T. 2005. Insights: Children and Young People Speak Out About Family Discipline. Wellington: Save the Children.

Durrant, J.E., and R. Ensom. 2017. Twenty-Five Years of Physical Punishment Research: What Have We Learned? Journal of Korean Academy of Child and Adolescent Psychiatry 28 (1): 20-24.

Elgar, F.J., P.D. Donnelly, V. Michaelson, G. Gariépy, K.E. Riehm, S.D. Walsh, and W. Pickett. 2018. Corporal Punishment Bans and Physical Fighting in Adolescents: An Ecological Study of 88 Countries. British Medical Journal Open 8: 1-8.

Ellonen, N., C. Jernbro, S. Janson, Y. Tindberg, and S. Lucas. 2015. Current Parental Attitudes Towards Upbringing Practices in Finland and Sweden 30 Years After the Ban on Corporal Punishment. Child Abuse Review 24 (6): 409-417.

Foster, D. 2020. An Overview of Child Protection Legislation in England, (Briefing Paper, Number 6787, 19 February 2020). London: House of Commons Library.

Frawley, A. 2018. The Dystopia of the Child-Protection Industry. Spiked, 9 August [Online]. https://www. spiked-online.com/2018/08/09/the-dystopia-of-the-child-protection-industry/. Accessed 2 May 2021.

Gershoff, E.T. 2002. Corporal Punishment by Parents and Associated Child Behaviors and Experiences: A Meta-Analytic and Theoretical Review. Psychological Bulletin 128 (4): 539-579.

Global Initiative to End All Corporal Punishment of Children. 2021. Progress. https://endcorporalpuni shment.org/countdown/. Accessed 20 April 2021.

GOV.UK. 2019a. Devolution Settlement: Northern Ireland. https://www.gov.uk/guidance/devolution-settl ement-northern-ireland. Accessed 31 Jan 2021.

GOV.UK. 2019b. Devolution Settlement: Scotland. https://www.gov.uk/guidance/devolution-settlementscotland. Accessed 31 Jan 2021.

Gracia, E., and J. Herrero. 2008. Is it Considered Violence? The Acceptability of Physical Punishment of Children in Europe. Journal of Marriage and Family 70 (1): 210-217.

Gunnoe, M.L., and C.L. Mariner. 1997. Toward a Developmental-Contextual Model of the Effects of Parental Spanking on Children's Aggression. Archives of Pediatrics and Adolescent Medicine 151 (8): 768-775.

Hain, R.D.W. 2000. Occasional Smacking Does no Harm, British Medical Journal, 320(1538). Available at: https://www-bmjcom.ergo.southwales.ac.uk/content/320/7248/1538.2. Accessed 25 Jan 2021.

Heilmann, A., Kelly, Y. and Watt, R. G. 2015. Equally Protected? A Review of the Evidence on the Physical Punishment of Children. Glasgow National Society for the Prevention of Cruelty to Children.

Hicks-Pass, S. 2009. Corporal Punishment in America Today: Spare the Rod, Spoil the Child? A Systematic Review of the Literature. Best Practices in Mental Health 5 (2): 71-88.

Home Office. 1989. Children Act 1989. Norwich: The Stationery Office. 
Home Office. 2004. Children Act 2004. Norwich: The Stationery Office.

Home Office. 2017. Children and Social Work Act 2017. Norwich: The Stationery Office.

Home Office. 1988. Criminal Justice Act 1988. Norwich: The Stationery Office.

Home Office. 1996. Education Act 1996. Norwich: The Stationery Office.

Home Office. 1986. Education (No. 2) Act 1986. Norwich: The Stationery Office.

Home Office. 1861. Offences Against the Person Act 1861. Norwich: The Stationery Office.

Home Office. 1998. School Standards and Framework Act 1998. Norwich: The Stationery Office.

Home Office. 2006. The Law Reform (Miscellaneous Provisions) (Northern Ireland) Order 2006. Norwich: The Stationery Office.

Juhasz, I., and M. Skivenes. 2017. The Population's Confidence in the Child Protection System-A Survey Study of England, Finland, Norway and the United States (California). Social Policy and Administration 51 (7): 1330-1347.

Keating, H. 2006. Protecting or Punishing Children: Physical Punishment, Human Rights and English Law Reform. Legal Studies 26 (3): 394-413.

Lansford, J.E., C. Cappa, D.L. Putnick, M.H. Bornstein, K. Deater-Deckard, and R.H. Bradley. 2017. Change Over Time in Parents' Beliefs About and Reported Use of Corporal Punishment in Eight Countries With and Without Legal Bans. Child Abuse and Neglect 71: 44-55.

Larzelere, R.E. 2000a. Child Outcomes of Non-Abusive and Customary Physical Punishment by Parents: An Updated Literature Review. Clinical Child and Family Psychology Review 3 (4): 199-221.

Larzelere, R.E. 2000b. Weak Evidence for Smacking Ban'. British Medical Journal 320: 1538.

Mappa. 2021. Details of Multi agency Protection arrangmenst, at Multi-Agency Public Protection Arrangements-MAPPA. justice.gov.uk. Accessed 20 Jul 2021.

McCoskrie, B. 2019. Defying Human Nature: An Analysis of New Zealand's 2007 Anti-Smacking Law. Manukau City: Family First NZ.

Morris, S. 2020. Wales to Ban Parents Smacking Their Children From 2022. The Guardian, 28 January [Online]. https://www.theguardian.com/politics/2020/jan/28/wales-to-ban-parents-smackingtheir-children-from-2022. Accessed 2 May 2021.

McTavish, J.R., M. Kimber, K. Devries, M. Colombini, J.C.D. MacGregor, C.N. Wathen, A. Agarwal, and H.L. MacMillan. 2017. 'Mandated Reporters' Experiences with Reporting Child Maltreatment: A Meta-Synthesis of Qualitative Studies. British Medical Journal Open 7 (10): 1-10.

Mosalski, R. 2020. Controversial 'smacking ban' will cost up to £8m to bring into action in Wales available at Controversial 'smacking ban' will cost up to $£ 8 m$ to bring into action in Wales Wales Online. Accessed 25 May 2021.

NAW (National Assembly for Wales). 2011. Rights of Children and Young Persons (Wales) Measure 2011. Cardiff: National Assembly for Wales.

Office for National Statistics. 2020. Population Estimates for the UK, England and Wales, Scotland and Northern Ireland: Mid-2019. https://www.ons.gov.uk/peoplepopulationandcommunity/popul ationandmigration/populationestimates/bulletins/annualmidyearpopulationestimates/mid2019est imates. Accessed 31 Jan 2021.

Pete, S. 1998. To Smack or Not to Smack? Should the Law Prohibit South African Parents from Imposing Corporal Punishment on Their Children? South African Journal on Human Rights 14 (3): 430-460.

Pfeiffer, C. 2014. Parallel Justice: Why Do We Need a Strengthening of the Victim in Society? in Coester, M. and Marks, E. (Eds) International Perspectives of Crime Prevention 6: Contributions from the 7th Annual International Forum 2013 within the German Congress on Crime Prevention. Mönchengladbach: Forum Verlag Godesberg

Scottish Government. 2019. Children (Equal Protection from Assault) (Scotland) Act 2019 Implementation Group. https://www.gov.scot/groups/children-equal-protection-from-assault-scotland-actimplementation-group/. Accessed 2 Feb 2021.

Scottish Government. 2020. Physical Punishment and Discipline of Children: How the Law is Changing. https://www.gov.scot/publications/physical-punishment-and-discipline-of-children-how-thelaw-is-changing/. Accessed 2 Feb 2021.

Scottish Parliament. 2019. Children (Equal Protection from Assault) (Scotland) Act 2019. Edinburgh: Scottish Parliament.

Scottish Parliament. 2018. Children (Equal Protection from Assault) (Scotland) Bill. Edinburgh: Scottish Parliament. 
Scottish Parliament. 2017a. Children (Equal Protection from Assault) (Scotland) Bill: A Proposal for a Bill to Give Children Equal Protection from Assault by Prohibiting the Physical Punishment of Children by Parents and Others Caring for or in Charge of Children: Consultation by John Finnie MSP Scottish Green Party Member for the Highlands and Islands. Edinburgh: Scottish Parliament.

Scottish Parliament. 2003. Criminal Justice (Scotland) Act 2003: Explanatory Notes. Edinburgh: Scottish Parliament.

Scottish Parliament. 2017b. Proposed Children (Equal Protection from Assault) (Scotland) Bill. https://www.parliament.scot/parliamentarybusiness/Bills/104602.aspx. Accessed 2 Feb 2021.

Scottish Parliament. 2017c. Proposed Children (Equal Protection from Assault) (Scotland) Bill: John Finnie MSP: Summary of Consultation Responses. Edinburgh: Scottish Parliament.

Senedd Cymru. 2019. Children (Abolition of Defence of Reasonable Punishment) (Wales) Act 2020: Issue Details. https://business.senedd.wales/mgIssueHistoryHome.aspx? $\mathrm{IId}=24674$. Accessed 6 Feb 2021.

Senedd Cymru. 2020a. Children (Abolition of Defence of Reasonable Punishment) (Wales) Act 2020. Cardiff: Senedd Cymru.

Senedd Cymru. 2020b. Terms of Reference: Operations, Guidance and Training: Task and Finish Group: Children (Abolition of Defence of Reasonable Punishment) (Wales) Act 2020. Cardiff: Senedd Cymru.

Straus, M.A. 2017. Beating the Devil Out of Them: Corporal Punishment in American Families and its Effects on Children. New York: Routledge.

The Telegraph. 2020. Wales Joins Scotland in Banning Smacking of Children. The Telegraph, 29 January [Online]. https://www.telegraph.co.uk/news/2020/01/29/wales-joins-scotland-banningsmacking-children/. Accessed 2 May 2021.

Tirosh, E., S.O. Shechter, A. Cohen, and M. Jaffe. 2003. Attitudes Towards Corporal Punishment and Reporting of Abuse. Child Abuse and Neglect 27 (8): 929-937.

United Nations. 2006. Committee on the Rights of the Child, available at OHCHRICommittee on the Rights of the Child. Accessed 25 May 2021.

UNICEF. 2014. Every Child Counts, available at SOWC 2014.pdf (unicef.org). Accessed 27 July 2021.

Welsh Government. 2020a. Children (Abolition of Defence of Reasonable Punishment) (Wales) Act 2020: Explanatory Memorandum: Incorporating the Regulatory Impact Assessment and Explanatory Notes. Cardiff: Welsh Government.

Welsh Government. 2020b. Welsh Government Integrated Impact Assessment Summary: Justice Impact Assessment (Annex D). Cardiff: Welsh Government.

Welsh Government. 2020c. Children (Abolition of Defence of Reasonable Punishment) (Wales) Act 2020 (legislation.gov.uk). Accessed 25 May 2021.

Wegner, P.D. 2005. Discipline in the Book of Proverbs: To Spank or Not to Spank. Journal of the Evangelical Theological Society 48 (4): 715-732.

Whewell, T. 2018. Norway's Hidden Scandal. BBC, 3 August [Online]. https://www.bbc.co.uk/news/ resources/idt-sh/norways_hidden_scandal. Accessed 2 May 2021.

Publisher's Note Springer Nature remains neutral with regard to jurisdictional claims in published maps and institutional affiliations. 